\title{
Ownership Structure and Financial Performance of Listed Firms in Kenya: Mediation Role of Corporate Diversification
}

\author{
Dr. Peninah Jepkogei Tanui ${ }^{1}$, Harrison Katana ${ }^{2}$, Geoffrey Alosi ${ }^{3}$, Lynda Khahenda ${ }^{4}$, Vincensia \\ Emmanuel Adhiambo 5
}

${ }^{1}$ Alupe University College, Kenya

${ }^{2}$ Kaimosi Friends University College, Kenya

${ }^{3}$ Kaimosi Friends University College, Kenya

${ }^{4}$ Kaimosi Friends University College, Kenya

${ }^{5}$ Kaimosi Friends University College, Kenya

\begin{tabular}{|c|c|}
\hline Article Info & Abstract \\
\hline Article history: & Purpose: The study aimed at examining the mediating role of corporate \\
\hline Received:26 February 2021 & diversification between ownership structure and financial performance of \\
\hline Revised: 13 April 2021 & listed firms in Kenya. \\
\hline Accepted: 13 April 2021 & $\begin{array}{l}\text { Methodology/Approach/Design: As guided by explanatory research design, } \\
65 \text { listed firms from } 2003 \text { to } 2017 \text { were targeted. However, panel data of } 35\end{array}$ \\
\hline Keywords: & $\begin{array}{l}\text { firms were considered after excluding suspended and delisted as far as the } \\
\text { study period is concerned. }\end{array}$ \\
\hline Corporate Diversification & Results: The panel regression analysis finding indicated that corporate \\
\hline Financial Performance & diversification positively and significantly mediated between institutional \\
\hline Ownership & ownership and financial performance $(\beta=.005, p$-value $=.000)$. \\
\hline Institutional Ownership & $\begin{array}{l}\text { Furthermore, there was a negative but statistically significant mediation effect } \\
\text { of corporate diversification between foreign ownership and financial }\end{array}$ \\
\hline JEL: H32, C33, O54, G30. & $\begin{array}{l}\text { performance }(\beta=-.0019, p \text {-value }=.023) \text {. These mediation effects existed } \\
\text { despite the direct effect between institutional and as well foreign ownership }\end{array}$ \\
\hline Paper Type : & and financial performance being statistically insignificant. \\
\hline Research Article & $\begin{array}{l}\text { Practical Implications: The study, therefore, suggested to the management of } \\
\text { listed firms to ensure proper implementation of corporate diversification as it }\end{array}$ \\
\hline Corresponding Author: & $\begin{array}{l}\text { transmits the effect of ownership structure on financial performance. More } \\
\text { importantly, policymakers are suggested to streamline taxation of foreign }\end{array}$ \\
\hline $\begin{array}{l}\text { Dr. Peninah Jepkogei Tanui } \\
\text { Email: }\end{array}$ & $\begin{array}{l}\text { investors, tackle malpractices in the firm leading to embezzlement of investor } \\
\text { funds. Future studies need to enlarge the scope to incorporate unlisted firms } \\
\text { as well as firms listed in different stock exchanges in East Africa. Other types }\end{array}$ \\
\hline tanuipenina@gmail.com & $\begin{array}{l}\text { of ownership structure as managerial, family and state need to be analyzed. In } \\
\text { addition, other forms and measures of corporate diversification could be } \\
\text { investigated by future researchers. }\end{array}$ \\
\hline & $\begin{array}{l}\text { Originality/Value: To attain the main objective, the study used panel } \\
\text { regression analysis and path diagrams to examine the effect of ownership } \\
\text { structure on financial performance via corporate diversification. }\end{array}$ \\
\hline
\end{tabular}

\section{Introduction}

In Kenya, the Nairobi Securities Exchange (NSE) since its inception in 1954 has been providing a trading platform for listed securities. Thus, NSE remains the largest securities exchange in East and Central Africa with an average market capitalization of United States Dollars (USD) 20 billion (NSE, 2018). This has been attributed to the growing number of listed firms from 48 in 2005 to 65 in June 2018. Despite their giant sizes, professional management, high turnover and asset value compared to unlisted counterparts (Ayot, 2013), rekindling performance in listed firms remains as the top agenda year in year out. For some years now, Kenya Airways, Mumias 
Sugar, and Uchumi Supermarket Limited are among the listed companies who have been experiencing deteriorating financial performance hence the implementation of drastic turnaround strategies such as cost-cutting, enhancing existing products, developing new products, market share extension, management, and financial restructuring. As one of the listing rules set by NSE, the ownership structure of a firm is a key requirement. As a result, the study assessed the effect of ownership structure on financial performance. As opined by (Leech \& Leahy, 1991), owners can be identified based on their type which in the study comprised of institutional and foreign ownership. This is because institutional investors are known to be the major actors given the intensity of their investment in most firms across the globe (Gharbi \& Jarboui, 2017). In the same breath, foreign investors play a key role given their ability to provide gigantic resources (Ongore, 2011) to diversify their portfolios (Thai, 2019).

At the outset, institutional ownership in most studies has been found to positively relate to firm performance. This is apparent from studies done in Pakistan (Hussain Tahir, 2015), and China (Zhang \& Kyaw, 2016). Lastly, a positive relationship between foreign ownership and firm performance exists in studies conducted in Croatia (Pervan, Pervan, \& Todoric, 2012) and Kenya (Ongore, 2011). In the same vein, there exist a U- shaped as reported by (Greenaway, Guariglia, \& Yu, 2014) in China, Slovakia Republic (Hintošová \& Kubíková, 2016) while a concave relationship was found in Vietnam by (Phung \& Mishra, 2016) between foreign ownership and firm performance. To come to the point, most of the studies relating to the two types of ownership structure to performance have been done globally, regionally and locally with inadequate linkages to other themes. To address the existing gap, the study brought in the corporate diversification concept which arises as part of investment decisions.

Corporate diversification has been found to benefit the managers and the firm at large. For managers, they can earn more compensation, power and prestige which is mainly associated with diversified firms (Jensen, 1986; Jensen \& Murphy, 1990). Through diversification, managers can reduce the unsystematic risks which are associated with an investment in a particular asset (Aggarwal \& Samwick, 2003). On the other hand, diversification is used by the firm as a strategic management option that enhances its market power (Montgomery, 1994) leading to competitive advantage (Foong \& Idris, 2012). Through corporate diversification, the firm is in a better position to boost its performance (Krivokapic, Njegomir, \& Stojic, 2017). These include both accounting and the general market performance (Palich, Cardinal, \& Miller, 2000), investment opportunities (Pawaskar, 1999), and efficient utilization of resources (Montgomery, 1994). From previous studies, institutional ownership positively affects corporate diversification (Gharbi \& Jarboui, 2017). On the other hand, foreign ownership negatively impacts corporate diversification decisions (Phung, Phan, Nguyen, \& Le, 2016). In regards to the relationship between corporate diversification and performance, mixed results have been reported in most countries. These include Croatia (Pavić \& Pervan, 2010), Pakistan (Iqbal, Hameed, \& Qadeer, 2012), South Africa (Oyekunle et al. 2013), Malaysia (Doaei, Ahmad Anuar, \& Ismail, 2014), Netherlands, Italy, and Turkey (Akpinar \& Yigit, 2016), Serbia (Krivokapic et al., 2017), France (Jouida \& Hellara, 2018), Vietnam (Phung \& Mishra, 2016) and Kenya (Manyuru, Wachira, \& Amata, 2017). Despite the exemplary effort by many

Copyright (C) 2021, Journal of Advanced Research in Economics and Administrative Sciences (JAREAS), Under a Creative Commons Attribution 4.0 International License 
researchers in analysing the direct relationships between forms of ownership structure, corporate diversification and performance, there was a clear gap to be filled by the study.

\section{Literature Review}

\section{Theoretical Perspective}

The study was anchored on Agency theory by (Jensen \& Meckling, 1976). In the recent past, ownership has been basing on the ability of a shareholder to influence a firm's practices. Active shareholders on the other hand engage in influencing corporations' policies and practices hence take a long-term perspective given investments. Agency theory was used by (Chen \& Yu, 2012) to buttress studies linking ownership structure, corporate diversification, and financial performance. First and foremost, shareholders are principals who seek to maximize their wealth which in turn is determined by the firm's performance. For this reason, an agency relationship is created as they delegate managers in the firm to act on their behalf. Secondly, corporate diversification creates agency relationships between managers and shareholders (Hermalin \& Katz, 2000). However, managers who act on behalf of shareholders are found to play a crucial role in determining the outcomes of such investment strategy. Jensen (1986) posits that managers end up misusing free cash flows by entering into value-destroying mergers. Montgomery (1994) evaluates corporate diversification with the view that managers in such relationships reap more benefits at the expense of shareholders. These benefits include power and prestige (Jensen, 1986), managerial compensation (Jensen \& Murphy, 1990). Oijen \& Hendrikse (2002) and Jensen (1986)view given ability of managers to withhold free cash flows to invest in diversification projects beneficial to them. This can only be prevented through institutional ownership given the prowess of institutional investors in monitoring closely the manager's actions (Hossain, Prevost, \& Rao, 2001; Demiralp, D'Mello, Schlingemann, \& Subramaniam, 2011; Boone \& White, 2015; Lin \& Fu, 2017). Moreover, other than providing massive resources (Ongore, 2011), foreign investors are known to enhance corporate governance (Oxelheim \& Randøy, 2003; Mi Choi, Sul, \& Kee Min, 2012; Nakano \& Nguyen, 2013). Agency theory in this study thus formed the basis of conceptualizing the relationship between institutional as well as foreign ownerships, corporate diversification and financial performance.

\section{Empirical Review}

Efforts in most countries especially by policymakers, government, and firm's management have been made to enhance performance, both in the short and long run. Nevertheless, several exogenous factors affect performance in a firm. Other than increased globalization, rapid change in technology, market, and financial liberalization, the recent 2008/2009 financial crisis has derailed the performance of most firms. The giant crisis has negatively impacted firms (Claessens, Tong, \& Wei, 2012), industrial growth (Moore \& Mirzaei, 2016)and led to a decline in business formation (Klapper \& Love, 2011). Other than exogenous, the performance of firms has been affected by endogenous which mainly relate to corporate governance issues especially after the worst corporate accounting scandals in WorldCom, Enron, and Lehman Brothers companies. For listed firms, their performance is determined mainly by the level of stock market development which in turn according to (Demirgüç-Kunt \& Levine, 1996) relies on a regulatory

Copyright (C) 2021, Journal of Advanced Research in Economics and Administrative Sciences (JAREAS), Under a Creative Commons Attribution 4.0 International License 
and institutional system of the country. Holding the exogenous factors determining performance constantly, firms continuously seek to understand the endogenous aspects that may be used as a strategy to boost performance. In particular, the study examined the ownership structure of the firm in relation to its financial performance. As set forth by agency theory proponents, a firm could not only reduce agency conflicts through the help of a well-defined ownership structure but also garner more performance (Jensen \& Meckling, 1976; Masry, 2016).

In most firms, the ownership structure is comprised of various investors who according to Leech \& Leahy (1991) can be grouped into distinct categories. When it comes to investment, such investors have diverse priorities and preferences (Thomsen \& Pedersen, 2000). More importantly, some investors tend to outshine others when it comes to issues touching on diversification and performance. More importantly, the study focused on institutional and foreign ownership of listed firms in Kenya. First and foremost, institutional investors tend to monitor actively thereby putting more pressure on managers towards performance as opposed to their opportunistic behaviours(Demiralp et al., 2011; Boone \& White, 2015; Lin \& Fu, 2017). Consequently, institutional investors with their conspicuous control (Gomez, 2014) are well known as major actors (Gharbi \& Jarboui, 2017). Secondly, foreign investors are known for their intentions of diversifying their portfolios (Thai, 2019). As a result, foreign investors provide their valuable independent monitoring role (Huang \& Shiu, 2009); (Nakano \& Nguyen, 2013) and massive resources (Ongore, 2011). Through their strong network and reputation (Li, Yue, \& Zhao, 2009), foreign investors in the firm ease access to external financing (Mihai, 2012)and other firm-specific assets (Kimura \& Kiyota, 2007).

\section{Relationship between Institutional Ownership and Financial Performance}

Institutional investors are said to possess active behavior if they have investment relationships with the firm only (Chen, Harford, \& Li, 2007). On the other hand, passive institutional investors hold both investment and business relations with the firm. Regardless of the categorization of institutional investors, some researchers have widened the scope when evaluating the effect of institutional ownership on firm performance by including other aspects rather than financial performance. For instance, institutional investors positively affect the firm's performance through their ability to limit the self-serving behaviors of managers (Demiralp et al., 2011). Hussain Tahir (2015) assessed institutional ownership in relation to corporate value. Moreover, Institutional investors are known for influencing both the types and levels of risks relating to investment decisions (Al-Thuneibat, 2018) and increasing transparency by management in the firm (Boone \& White, 2015). To sum up, a positive relationship existed between institutional ownership and firm performance from the perspective that institutional investors play an active monitoring role, enhance shareholder value, attract analysts and reduce insider ownership (Lin \& $\mathrm{Fu}, 2017)$. Given strong business ties, institutional investors in Kenya were found to be inactive as far as the monitoring role is concerned.

In relation to institutional ownership and firm performance, significant studies have been conducted across the globe. Thomsen \& Pedersen (2000) sampled 435 largest European companies to evaluate the effect of ownership structure on firm performance. In this study,

Copyright (C) 2021, Journal of Advanced Research in Economics and Administrative Sciences (JAREAS), Under a Creative Commons Attribution 4.0 International License 
institutional ownership had a positive and significant relation to firm performance. Bhattacharya \& Graham (2009) evaluated the relationship between institutional ownership and firm performance among 116 firms from Finland's industry sector. Institutional ownership aspects analyzed were pressure-sensitive (include insurance companies, banks, and non-bank trusts) and resistant institutional shareholding (public pension funds, mutual funds, endowments and foundations). Institutional ownership stakes adversely affected performance measured using Tobin's q for pressure-sensitive institutional owners. Fazlzadeh, Hendi, \& Mahboubi (2011) examined 137 listed firms in Iran's Tehran stock exchange from 2001 to 2006. The findings indicated a significant positive relationship between institutional ownership and firm performance. This was attributed to their effectiveness in monitoring and provision of resources. A significant positive relationship between institutional ownership and performance of 73 listed firms in Egypt from 2007 to 2014 was reported by (Masry, 2016). In Indonesia, Saleh, Zahirdin, \& Octaviani (2017) sampled property and real estate public companies to assess the relationship between ownership structure and firm performance. Contrary to the partially significant effect of managerial ownership, institutional ownership was found to have a significant effect on firm performance. Zhang \& Kyaw (2016) conducted an empirical analysis to assess the relationship between ownership structure and performance among 1158 non-financial companies in China. In their study, a positive relationship exists between institutional ownership and firm performance In Jordan, Zraiq \& Fadzil (2018) assessed the impact of ownership structure on firm performance. It was found that institutional ownership had insignificant positive impact on firm's performance.

\section{Relationship between Foreign Ownership and Financial Performance}

Foreign investors in a firm play a key role that improves performance in the long run. Thus, anchoring on immense benefits associated with foreign ownership, researchers have purposed to find its relationship with firm performance. In China, Greenaway et al. (2014) used a sample size of 21582 unlisted firms from 2000 to 2005 to establish the relationship between foreign ownership and corporate performance. Findings indicated an inverted U-shaped relationship between foreign ownership and corporate performance. This implied that foreign ownership increases performance if below but decreases if beyond these turning points. The authors concluded that performance decline as foreign ownership becomes more concentrated in the firm. In Croatia, Pervan et al. (2012) assessed the relationship between ownership structure and a firm's ROA among listed firms at the Zagreb stock exchange from 2003 to 2010. Using 1430 observations, those firms controlled by foreign investors reported exemplary performance. In the Slovak Republic, Hintošová \& Kubíková (2016) collected data from domestic, foreign and jointly owned firms from 2004 to 2013. From the 2000 observations analyzed, foreign ownership and firm performance relationship were inverted U-shaped. This implied that foreign ownership ranging from 61 to $65 \%$ increased performance but declined subsequently. In Vietnam, Phung \& Mishra (2016) obtained data from listed firms from 2007 to 2012 whereby foreign ownership was found to have a concave relationship with performance. Hence, foreign ownership of up to a level of $43 \%$ increases performance while state ownership of the level above $28.67 \%$ increases performance. The study thus concluded the need to encourage foreign and widely spread state ownership to enhance firm performance. Zraiq \& Fadzil (2018) in

Copyright (C) 2021, Journal of Advanced Research in Economics and Administrative Sciences (JAREAS), Under a 
Jordan found that foreign ownership positively impacted on firm's performance. In Kenya, Ongore (2011) sampled 42 firms from different sectors listed at NSE to investigate the effect of ownership structure on firm performance. From analysis, there existed a significant positive relationship between foreign ownership and firm performance indicators. The researchers concluded that the findings vindicated the long-held belief that on average, foreign-owned companies perform better than their counterparts with dominant local ownership.

\section{Mediating Role of Corporate Diversification}

In most firms, the majority of the shareholders seek to maximize their wealth which in turn depends on the firm's performance. Therefore, given performance as the ultimate goal, owners in most firms seek to improve it. As pointed out by the modern portfolio theory, a firm's performance is enhanced as diversification minimizes systematic risks but maximizes expected returns (Markowitz, 1952). Besides, there exists a positive relationship between diversification and a firm's performance under the market power view of corporate diversification (Montgomery, 1994). In addition, there exists a positive liaison between corporate diversification and firm performance (Oyekunle Oyewobi et al., 2013);(Krivokapic et al., 2017);(Salma \& Hussain, 2018). To come to the point, the interests of agents and principals as set forth by agency theory proponents are brought into the limelight given decisions touching on a firm's diversification. Shareholders as principals, in that case, ownership structure have been linked to firm's performance via corporate diversification. From empirical studies, the mediating role of corporate diversification between ownership structure and a firm's performance has been overlooked. This happens despite corporate diversification mediating between debt financing and operating performance (Xu, Ou, \& Chen, 2016).(C.-J. Chen \& Yu, 2012) and (Phung, 2015) examined ownership structure, corporate diversification, and firm performance jointly. Notwithstanding this, corporate diversification was still defined as an independent variable.

As to fill the existing gap in literature, corporate diversification was defined as a mediator given the relationship between institutional as well as foreign ownerships and the financial performance of listed firms in Kenya. To begin with, Institutional ownership positively affects the corporate decisions in a firm (Gharbi \& Jarboui, 2017). On the other hand, there exists a linear relationship between institutional ownership and a firm's performance (Thomsen \& Pedersen, 2000); (Masry, 2016); (Zhang \& Kyaw, 2016). In this case, better performance is attained given the supervision pressure on management and resources provided by institutional investors (Fazlzadeh et al., 2011; Lin \& Fu, 2017; Zhang \& Kyaw, 2016). Sooner or later, firm performance is improved via diversification strategies in place as most institutional investors are watchful and vigilant with their investments (Chung \& Zhang, 2011). The study thus hypothesized:

$\mathrm{H}_{\mathrm{ola}}$; There is no significant relationship between institutional ownership and corporate diversification of firms listed at NSE in Kenya.

$\mathrm{H}_{\mathrm{o} 1 \mathrm{~b}}$; Corporate diversification does not mediate between institutional ownership and financial performance of firms listed at NSE in Kenya.

Copyright (C) 2021, Journal of Advanced Research in Economics and Administrative Sciences (JAREAS), Under a Creative Commons Attribution 4.0 International License 
Lastly, foreign ownership positively relates to firm performance (Pervan et al., 2012); (Ongore, 2011); (Hewa Wellalage \& Locke, 2015) as many foreign investors provide access to massive resources (Ongore, 2011), enhance good governance (Oxelheim \& Randøy, 2003), possess advanced managerial skills and technologies (Phung, 2015). For that reason, as foreign investors aspire to diversify their portfolios (Thai, 2019), the performance of the firm is boosted given the right decisions made regarding investments (Ongore, 2011). Foreign ownership was expected in the study to perk up performance in the firm through diversification strategies existing in the firm. As a result, the study sought to test hypotheses $\mathrm{H}_{\mathrm{o} 2 \mathrm{a}}$ and $\mathrm{H}_{\mathrm{o} 2 \mathrm{~b}}$;

$\mathrm{H}_{\mathrm{o} 2 \mathrm{a}}$; There is no significant relationship between foreign ownership and corporate diversification of firms listed at NSE in Kenya.

$\mathrm{H}_{\mathrm{o} 2 \mathrm{~b}}$; Corporate diversification does not mediate between foreign ownership and financial performance of firms listed at NSE in Kenya.

\section{Methodology and Procedures}

A post-positivist research paradigm was adopted given the objectivity of the study (Elshafie, 2013). Moreover, the paradigm assumes that knowledge is conjectural hence no absolute truth can be found which thus has led to the testing of hypotheses (Phillips \& Burbules, 2000). Using explanatory research design, 65 listed firms at NSE in Kenya from 2003 to 2017 were targeted. These firms are categorized under sectors like agricultural, automobile and accessories, banking, commercial and services, construction and allied, energy and petroleum, investment, insurance, and finally manufacturing and allied. Exclusion criteria were used since during the study period, some firms had been delisted or suspended. As a result, panel data was collected from audited financial reports of 35 listed firms. Analysis was conducted descriptively using mean, standard deviation, minimum and maximum. Furthermore, direction and strength of association between study variables were assessed using Pearson's product-moment correlation analysis. Prior to testing hypotheses, regression assumptions were evaluated. The following panel regression models were investigated;

Mediating effect of corporate diversification (CD) in the relationship between institutional ownership (IO) and financial performance (FP);

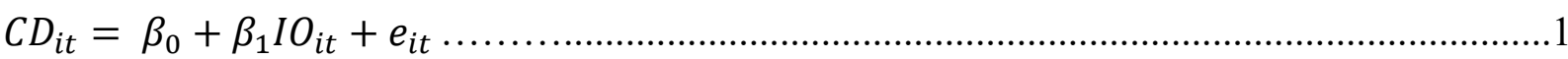



Mediation effect (indirect effect) $=\beta_{1} * \beta_{3}$

Direct effect $=\beta_{2}$

Total effect $=\beta_{2}+\left(\beta_{1} * \beta_{3}\right)$

Mediating effect of corporate diversification (CD) in the relationship between foreign ownership (FO) and financial performance (FP);



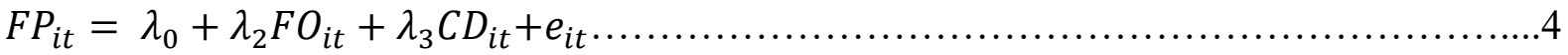

Mediation effect (indirect effect) $=\lambda_{1} * \lambda_{3}$

Direct effect $=\lambda_{2}$

Total effect $=\lambda_{2}+\left(\lambda_{1} * \lambda_{3}\right)$

Copyright (C) 2021, Journal of Advanced Research in Economics and Administrative Sciences (JAREAS), Under a Creative Commons Attribution 4.0 International License 


\section{Measurement of Variables}

This study adopted Tobin's q formula as modified by Chung and Pruitt (1994) to measure financial performance indicators (Phung \& Mishra, 2016); (Manyuru et al., 2017); (Saleh et al., 2017). As the first independent variable, institutional ownership was measured following the approach by (Saleh et al., 2017) who measured institutional ownership as the percentage of shares owned by institutional investors from both financial and non-financial organizations. Secondly, foreign ownership was based on the percentage of shares owned by non-citizens or foreign investors (Ongore, 2011); (Hintošová \& Kubíková, 2016). The study followed the definition of corporate diversification by (Doaei et al., 2014), (Monteforte \& Staglianò, 2015), (Nzioka, 2017) who defined it in relation to product. Hence, this mediating variable was measured using Jacquemin and Berry's Entropy approach which was tandem with (Akpinar \& Yigit, 2016), (Phung \& Mishra, 2016) and (Krivokapic et al., 2017).

\section{Results and Discussion}

\section{Descriptive Statistics and Correlation Analysis Findings}

Given the results in Table 1, the correlation between FO and CD was the strongest although insignificant $(r=0.0849, p>0.01)$ followed by IO and FP $(r=0.0676, p>0.01)$. The results in Table 1 showed that FP recorded a minimum of -0.33 and a maximum of 29.833 with a mean of 1.2059 and a standard deviation of 2.0244. Primarily, the negative sign implied that some firms recorded some losses during the study period. The results on IO were found to have a mean of 34.4498 percent and a standard deviation of 23.8492. The study also found the minimum percentage of a firm's shares owned by both financial and non-financial institutions in the firm was 0.25 percent and the maximum percentage of 87.14 percent. Therefore, institutional investors have invested heavily in most firms.

Table 1: Descriptive Statistics and correlation analysis

\begin{tabular}{lllllllll}
\hline & Mean & Std. Dev. & Min. & Max. & FP & IO & FO & CD \\
\hline FP & 1.2059 & 2.0244 & -0.33 & 29.833 & 1 & & & \\
IO & 34.4498 & 23.8492 & 0.25 & 87.14 & 0.0676 & 1 & & \\
FO & 29.4433 & 28.6719 & 0 & 94.04 & -0.0128 & $-0.6025^{* *}$ & 1 & \\
CD & 0.5877 & 0.4105 & 0 & 1.523 & $-0.3242^{* *}$ & $-0.1834 * *$ & 0.0849 & 1 \\
\hline
\end{tabular}

** Correlation is significant at the 0.01 level (2-tailed)

The percentage of shares owned by non-citizens or foreign investors (FO) in the study comprised those non-Kenyan individuals and institutions incorporated in other countries. From the results presented in Table 1, FO had an average shareholding of 29.4433 percent and a standard deviation of 28.6719. In addition, FO also had a minimum percentage of zero and a maximum percentage of 94.04. The minimum percentage of FO showed that some of the firms under the study had almost 100 percent shareholders being Kenyans. CD, the act by the firm to enter into new markets and or product to existing ones was found to have a mean of 0.5877 and 0.4105 standard deviation proportion of a firm's total sales from its product. Compared to all other variables, $C D$ had the least mean and standard deviation. The latter implies that most

Copyright (C) 2021, Journal of Advanced Research in Economics and Administrative Sciences (JAREAS), Under a 
observations were very close to the average. For $\mathrm{CD}$, the minimum value was zero while the maximum is 1.523 .

\section{Panel unit root test}

One of the important properties of the panel series process is the stationarity of data. A random process or a stochastic process is known to be stationary when its joint distribution doesn't change over time. The study employed panel unit root tests as Levin-Lin-Chu (LLC)(Levin, Lin, \& Chu, 2002), Harris-Tzavalis(Harris \& Tzavalis, 1999), and Im-Pesaran-Shin (IPS)(Im, Pesaran, \& Shin, 2003). It was found that IO, FO, CD, and FP were all stationary at levels.

Table 2: Panel unit root test

\begin{tabular}{|c|c|c|c|c|c|}
\hline \multirow[t]{6}{*}{ LLC } & $\begin{array}{l}\text { Time trend } \\
\text { included }\end{array}$ & $\mathbf{F P}$ & IO & FO & CD \\
\hline & t-statistic & -4.1496 & -10.1991 & -9.3434 & -2.5530 \\
\hline & $\mathrm{p}$-value & 0.0000 & 0.0000 & 0.0000 & 0.0053 \\
\hline & Time trend & ded & & & \\
\hline & t-statistic & -5.7228 & -12.9750 & -10.7578 & -4.5541 \\
\hline & p-value & 0.0000 & 0.0000 & 0.0000 & 0.0000 \\
\hline \multirow[t]{7}{*}{$\begin{array}{l}\text { Harris- } \\
\text { Tzavalis }\end{array}$} & $\begin{array}{l}\text { Time trend } \\
\text { included }\end{array}$ & & & & \\
\hline & z-statistic & -22.9649 & -32.6103 & -26.9181 & -21.3611 \\
\hline & p-value & 0.0000 & 0.0000 & 0.0000 & 0.0000 \\
\hline & Time trend & ded & & & \\
\hline & z-statistic & -36.7596 & -53.8587 & -44.4750 & -35.6960 \\
\hline & p-value & 0.0000 & 0.0000 & 0.0000 & 0.0000 \\
\hline & $\begin{array}{l}\text { Time trend } \\
\text { included }\end{array}$ & & & & \\
\hline \multirow{5}{*}{ IPS } & Z-statistic & -10.8979 & -15.4345 & -13.7009 & -11.8102 \\
\hline & p-value & 0.0000 & 0.0000 & 0.0000 & 0.0000 \\
\hline & Time trend & ded & & & \\
\hline & z-statistic & -9.8590 & -15.4147 & -13.4246 & -11.5979 \\
\hline & p-value & 0.0000 & 0.0000 & 0.0000 & 0.0000 \\
\hline
\end{tabular}

* For LLC, Harris-Tzavalis and IPS Panel unit root test (Ho; All panels contain a unit root)

\section{Regression Analysis Assumptions}

A normality test was done to determine whether sampled data under study were normally distributed. From the Shapiro-Wilk test, panel data were normally distributed (p-values >0.05). The average Variance Inflation Factor (VIF) values for study variables were found to be less than 10. Breusch-Pagan/Cook-Weisberg test was conducted and found that variance of residuals variance was homogeneous. Lastly, there was no autocorrelation detected given the Durbin Watson (DW) statistic.

Copyright (C) 2021, Journal of Advanced Research in Economics and Administrative Sciences (JAREAS), Under a 


\section{Mediating Effect of Corporate Diversification between Institutional Ownership and Financial Performance}

Table 3 presents the results of the direct and mediation effect (indirect) of CD on IO and the firm's FP. It was found that institutional ownership had a negative and significant relationship with the corporate diversification with the $\beta=-0.003$ and p-value $=0.000<0.05$ (path $a$ ). From this, the hypothesis; Hola; There is no significant relationship between institutional ownership and corporate diversification of firms listed at NSE in Kenya was rejected and the study concluded that institutional ownership structure significantly affects corporate diversification of firms listed in NSE. This is inconsistent with the finding by (Gharbi \& Jarboui, 2017) as the presence of institutional investors to be having a significant impact on the corporate diversification decisions of the firm.

Table 3: Mediation Effect of Corporate Diversification on Institutional Ownership and Financial Performance

\begin{tabular}{lllll}
\hline Variables & Estimate & Std. Error & z-value & $\mathbf{P}(>|\mathbf{z}|)$ \\
\hline CD & & & \\
IO & -0.0032 & 0.0007 & -4.285 & 0.000 \\
Intercept & 0.6964 & 0.03099 & 22.472 & 0.000 \\
& & & \\
\hline FP & & & \\
\hline CD & -1.5911 & 0.2077 & -7.660 & 0.000 \\
IO & 0.0007 & 0.0036 & 0.201 & 0.841 \\
Intercept & 2.1163 & 0.2064 & 10.254 & 0.000 \\
& & & & \\
\hline Defined Parameters & & & & \\
\hline Indirect Effects & 0.0051 & 0.0013 & 3.735 & 0.000 \\
Direct Effects & 0.0007 & 0.0035 & 0.201 & 0.841 \\
Total Effects & 0.0058 & 0.0037 & 1.553 & 0.120 \\
\hline Source:Researcher's & & & \\
\hline
\end{tabular}

Source: Researcher's Computation, 2019. R Output Results

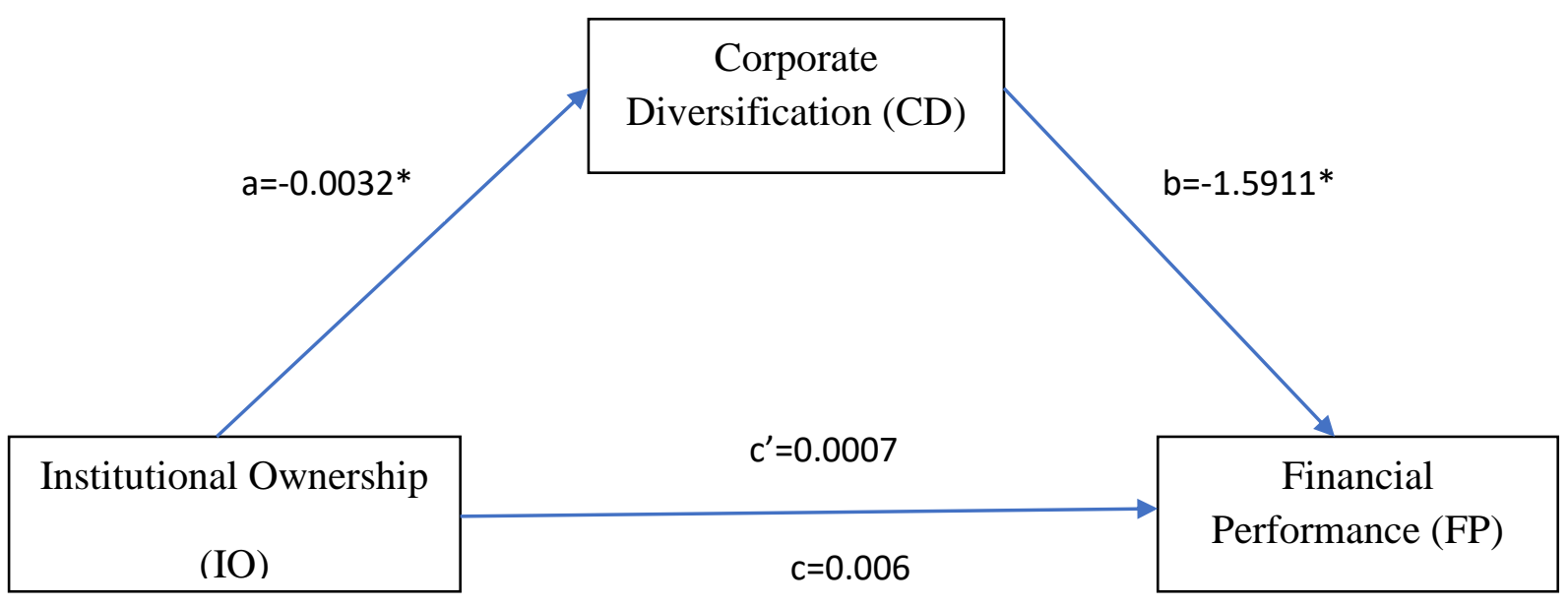

Copyright (C) 2021, Journal of Advanced Research in Economics and Administrative Sciences (JAREAS), Under a 


\section{Figure 1: Path diagram for Mediation Effect of Corporate Diversification on Institutional Ownership and Financial Performance}

In Table 3, the direct effect (path c') was positive $(\beta=.0007)$ but not statistically significant (pvalue $=.841>.05$ ). According to (Baron \& Kenny, 1986), there is no need to establish mediation if the direct effect is not significant. However, (Zhao, Lynch Jr, \& Chen, 2010) dismisses this as a wrong intuition and thus concludes that there is no need for the direct effect to be significant for mediation to take place. Basing on (Zhao et al., 2010), the study proceeded to establish the mediating effect of CD even though the direct relationship (effect of IO on FP) was not significant. It was also evident that $\mathrm{CD}$ had a positive and significant mediating effect between the IO and the FP of the firm in NSE as shown in Table 3 with $\beta=.005\left(-.003^{*}-1.591\right)$ which means path $\mathrm{a} *$ path $\mathrm{b}$ ) estimates and probability $.000<.05$. In this case, the hypothesis; Holb; Corporate diversification does not mediate the relationship between institutional ownership and financial performance of firms listed at NSE in Kenya was rejected and thus concluded that corporate diversification mediates the relationship between institutional ownership and financial performance of the listed firms in NSE. Both the direct and indirect effects pointed in the same direction hence indicated the existence of complementary mediation according to (Zhao et al., 2010)popularly known as partial mediation by (Baron \& Kenny, 1986). This implies that two listed firms who differ by 1 unit in their IO are estimated to differ by 0.005 units in FP as a result of the tendency for the firm with more IO to diversify less (path a was negative). This sequentially resulted in less FP (path $\mathrm{b}$ was negative). The finding that IO negatively related to CD disagreed with the finding by (Gharbi \& Jarboui, 2017) who reported a positive relationship.

Total effect (path $\mathrm{c}$ ) was found to be positive $(\beta=.006)$ and insignificant ( $p$-value=.120> .05). The implication was that two listed firms who differ by 1 unit in IO are estimated to differ by 0.006 units in their FP. For instance, the positive coefficient of total effect meant that higher levels of IO in the firm resulted in higher FP. This finding is in tandem with those reported by (Thomsen \& Pedersen, 2000), (Fazlzadeh et al., 2011), (Hussain Tahir, 2015), (Masry, 2016), (Zhang \& Kyaw, 2016),(Lin \& Fu, 2017). The results of mediating effect of Corporate Diversification between Institutional Ownership and Financial Performance can be fitted in regression equations 3.8 and 3.9 as follows;



The mediation effect (indirect effect) of 0.0051 is the product of coefficients $(-0.0032 *-1.5911)$.

Mediating Effect of Corporate Diversification between Foreign Ownership and Financial Performance

The study aimed also to find out the mediation effect on the relationship CD and FP of the listed firms in NSE. First and foremost, path $a$ indicated a positive relationship between the FO and $\mathrm{CD}(\beta=.001)$. Its $p$-value was .051>.05 implying that hypothesis ${ }_{\text {Hoza; }}$; that there is no significant relationship between foreign ownership and corporate diversification of firms listed at NSE in

Copyright (C) 2021, Journal of Advanced Research in Economics and Administrative Sciences (JAREAS), Under a 
Kenya also failed to be rejected. It was hence concluded that there exists no significant relationship between FO and CD. The finding thus supports the opinion by (Phung et al., 2016)foreign investors discourage corporate diversification despite playing a monitoring role in the firm.

Table 4: Mediation Effect of Corporate Diversification on Foreign Ownership and Financial Performance

\begin{tabular}{lllll}
\hline Variables & Estimate & Std. Error & z-value & $\mathbf{P}(>|\mathbf{z}|)$ \\
\hline $\mathrm{CD} \sim$ & & & \\
FO & & & & \\
Intercept & 0.0012 & 0.0006 & 21.538 & 0.051 \\
& 0.5518 & 0.0256 & & 0.000 \\
\hline FP & & & \\
\hline CD & & & -7.832 & 0.000 \\
FO & -1.6049 & 0.2049 & 0.357 & 0.721 \\
Intercept & 0.0010 & 0.0029 & 12.842 & 0.000 \\
& 2.1182 & 0.1649 & & \\
\hline Defined Parameters & & & & \\
\hline Indirect Effects & -0.0019 & 0.001 & -2.000 & 0.023 \\
Direct Effects & 0.0012 & 0.003 & 0.358 & 0.720 \\
Total Effects & -0.00071 & 0.003 & -0.293 & 0.770 \\
\hline
\end{tabular}

Source: Researcher's Computation, 2019. R Output Results



Figure 2: Path diagram for mediation effect of Corporate Diversification on Foreign Ownership and Financial Performance

Direct effect (path c') was found to be positive but not statistically significant $(\beta=.0012$; $p$ value $=.720>.05)$. Hence, listed firm with FO and equally diversify is estimated to be 0.0012 units higher in FP. The study proceeded to estimate the mediation effect of CD since (Zhao et al., 2010) points out the direct effect need not be significant. The mediation effect of corporate 
diversification or indirect effects (path a multiplied path b) was the product of .0012 and 1.6049) on the relationship between the foreign ownership and the performance of firms was negative and significant with $\beta=-.0019$ and $p$-value $=-.023<.05$ respectively. The hypothesis Hozb; Corporate diversification does not mediate the relationship between foreign ownership and financial performance of firms listed at NSE in Kenya was rejected. It, therefore, confirms that corporate diversification mediates between foreign ownership and a firm's financial performance. This mediation according to (Zhao et al., 2010)is competitive as direct and indirect effects point in opposite directions. The negative indirect effect implied that two listed firms who differ by 1 unit in their FO are estimated to differ by 0.0019 units in FP as a result of the tendency for the firm with more FO to diversify more (path a was positive). This in turn translated into less FP (path $\mathrm{b}$ was negative). Consequently, the negative link between CD and FP supported the finding by (Elango, Ma, \& Pope, 2008), (Pavić \& Pervan, 2010). Lastly, the total effect (path c) was negative $(\beta=-.0007)$ and not statistically significant ( $\mathrm{p}$-value $=.770>$ $.05)$. This implies that two firms who differ by 1 unit in their FO are estimated to differ by 0.0007 units in their FP. The negative coefficient of total effect implied that firms with greater FO reports less FP. This finding contradicts the positive relationship between FO and FP documented by (Ongore, 2011),(Pervan et al., 2012), and (Zraiq \& Fadzil, 2018). The results of mediating effect of Corporate Diversification between Foreign Ownership and Financial Performance can be fitted in regression equations 3.10 and 3.11 as follows;



$$
\begin{aligned}
& \text { (0.0256) (0.0006) }
\end{aligned}
$$



$$
\begin{aligned}
& \begin{array}{lll}
(0.1649) & (0.0029) \quad(0.2049)
\end{array}
\end{aligned}
$$

The mediation effect (indirect effect) of -0.0019 is the product of coefficients $(0.0012 *$ 1.6049).

\section{Conclusion and Suggestion}

Financial performance in a firm is determined by internal and external factors (Opler \& Titman, 1994); Hawawini et al., 2003; Almajali et al., 2012). To expound on internal factors, ownership structure was examined. Ideally in a listed firm, ownership in firms is held by individuals or groups in form of shares. Shareholders can either be from within or outside the firm (McCann \& Vroom, 2009) and seek to maximize their wealth. In the process of maximizing their wealth, shareholders according to Thomsen \& Pedersen (2000) are known to have varied investment priorities and preferences. The study thus accomplished the objective of extending existing knowledge by testing mediating effect of corporate diversification between institutional as well as foreign ownership and financial performance of listed firms at NSE in Kenya. Despite direct effect being statistically insignificant, corporate diversification mediated between institutional ownership and financial performance as well as between foreign ownership and financial performance. Thus, the study concluded that the need to have a statistically significant direct effect to test mediation as stated by (Baron \& Kenny, 1986) was not supported in the study. In tandem with (Zhao et al., 2010), mediating effect of Corporate Diversification existed even though the direct effect was not statistically significant.

Copyright (C) 2021, Journal of Advanced Research in Economics and Administrative Sciences (JAREAS), Under a 
Agency theory explains the agency relationships which arise as principals (shareholders) delegate authority to agents (managers) to perform various activities on their behalf (Jensen \& Meckling, 1976). In the study, ownership structure highlights the existence of shareholders who seek to acquire economic benefits through investments in the firm. Therefore, the study contributes to agency theory since it evaluates collectively the agency relationship created given investors as institutions, foreigners, and managers in progressing performance through corporate diversification. In light of research findings, recommendations have been directed to the management who are practically involved on behalf of shareholders in the day-to-day operations of listed firms. On average, institutional ownership was leading in the Automobile and accessories, and Insurance sectors. The management of firms listed in other sectors needs to emulate the two leading sectors by incorporating more institutions in their ownership structure. As a result, more pressure would be exerted on management through monitoring and control as set forth by (Shleifer \& Vishny, 1997), (Denis \& McConnell, 2003)which in the long run drives performance. Management of listed firms in other sectors is required to direct more interest towards foreign ownership even though as observed that on average most firms have a significant number of foreign investors. More importantly, regional integrations formed by the government need to be utilized to exert a pull of both foreign individuals and institutions to the firm's ownership structure. In most firms, corporate diversification aids a firm in extending its existing market or product lines. The study suggests that the management of listed firms could direct their attention in ensuring that corporate diversification strategies are properly implemented. Failure to do so, there is a possibility as opine by (Hitt, Hoskisson, \& Kim, 1997)that diversification might negatively affect performance.

The role of CMA in Kenya seeks to drive economic growth and development by enhancing capital flows, mobilizing long-term resources, and ensuring financial sector stability (CMA, 2017). As a key policymaker, the study suggests CMA's intervention in enhancing a firm's ownership structure which has been observed to positively affect financial performance. First and foremost, CMA is required to focus on malpractices associated with corporate governance which have increased embezzlement of investors' funds in a firm. Secondly, most foreign investors are willing to invest but are cautious with taxation. Therefore, to attract foreign investors, it is suggested that CMA would work with the Kenya Revenue Authority's (KRA) department of income tax in streamlining the filing of taxes by foreign investors. CMA could encourage the listing of more enterprises from the private sector as to attract more investors. Since most firms' private sector perform well, investors will be given an opportunity to diversify their portfolios hence further maximizing their wealth. NSE in Kenya provides a trading platform for securities of listed firms. Through decisions made by NSE, the ownership structure of the firms could be improved. NSE can enhance investor diversification by listing more firms as a result of creating awareness through listing forums.

This study has limitations that provide an opportunity for future research. Given the scope, future studies could incorporate unlisted firms in Kenya or move beyond territorial boundaries to investigate firms listed in stock exchanges found in East Africa. In regards to ownership structure, shareholders can be identified based on the fraction of shares they own (Demsetz, 1983)and categories as well (Leech \& Leahy, 1991). The study focused only on two categories

Copyright (C) 2021, Journal of Advanced Research in Economics and Administrative Sciences (JAREAS), Under a 
of shareholders arising given institutions and foreign investors. The study thus suggests further research to be conducted in relation to other types of shareholders as management or insider ownership, family, and government. Future scholars also need to assess the shareholders based on the fraction of shares or shareholding size; largest single owner, five (5) largest, ten (10) largest, and twenty (20) largest owners in the firm. The study recommends employing other measures and types of corporate diversification to evaluate its mediating role between ownership structure and financial performance.

\section{Conflict of Interest}

The authors of the article declare no conflict of interest.

\section{Funding}

This research study was not funded by any institution. The author conducted the study on his expenses.

\section{References}

Aggarwal, R. K., \& Samwick, A. A. (2003). Why do managers diversify their firms? Agency reconsidered. The Journal of finance, 58(1), 71-118.

Akpinar, O., \& Yigit, I. (2016). The Relationship between Diversification Strategy and Firm Performance in Developed and Emerging Economy Contexts: Evidence from Turkey, Italy and Netherlands. Economic and Social Development: Book of Proceedings, 583.

Al-Thuneibat, A. (2018). The Relationship between the Ownership Structure, Capital Structure and Performance. JABM JOURNAL of ACCOUNTING-BUSINESS \& MANAGEMENT, $1(25), 1-20$.

Almajali, A. Y., Alamro, S. A., \& Al-Soub, Y. Z. (2012). Factors affecting the financial performance of Jordanian insurance companies listed at Amman Stock Exchange. Journal of Management research, 4(2), 266.

Ayot, K. O. (2013). Capital Structure Of Listed Firms In Kenya: The Case Of Non Financial Firms. University of Nairobi.

Baron, R. M., \& Kenny, D. A. (1986). The moderator-mediator variable distinction in social psychological research: Conceptual, strategic, and statistical considerations. Journal of personality and social psychology, 51(6), 1173.

Bhattacharya, P. S., \& Graham, M. A. (2009). On institutional ownership and firm performance: A disaggregated view. Journal of Multinational Financial Management, 19(5), 370-394.

Boone, A. L., \& White, J. T. (2015). The effect of institutional ownership on firm transparency and information production. Journal of Financial Economics, 117(3), 508-533.

Chen, C.-J., \& Yu, C.-M. J. (2012). Managerial ownership, diversification, and firm performance: Evidence from an emerging market. International Business Review, 21(3), 518-534.

Chen, X., Harford, J., \& Li, K. (2007). Monitoring: Which institutions matter? Journal of Financial Economics, 86(2), 279-305.

Copyright (C) 2021, Journal of Advanced Research in Economics and Administrative Sciences (JAREAS), Under a Creative Commons Attribution 4.0 International License 
Chung, K. H., \& Zhang, H. (2011). Corporate governance and institutional ownership. Journal of financial and quantitative analysis, 46(1), 247-273.

Claessens, S., Tong, H., \& Wei, S.-J. (2012). From the financial crisis to the real economy: Using firm-level data to identify transmission channels. Journal of International Economics, 88(2), 375-387.

Demiralp, I., D'Mello, R., Schlingemann, F. P., \& Subramaniam, V. (2011). Are there monitoring benefits to institutional ownership? Evidence from seasoned equity offerings. Journal of Corporate Finance, 17(5), 1340-1359.

Demirgüç-Kunt, A., \& Levine, R. (1996). Stock markets, corporate finance, and economic growth: an overview. The World Bank Economic Review, 10(2), 223-239.

Demsetz, H. (1983). The structure of ownership and the theory of the firm. The Journal of law and economics, 26(2), 375-390.

Denis, D. K., \& McConnell, J. J. (2003). International corporate governance. Journal of financial and quantitative analysis, 38(1), 1-36.

Doaei, M., Ahmad Anuar, M., \& Ismail, Z. (2014). Diversification and financial performance in Bursa Malaysia. International Journal of Management and Business Research, 4(4), 309317.

Elango, B., Ma, Y. L., \& Pope, N. (2008). An investigation into the diversification-performance relationship in the US property-liability insurance industry. Journal of Risk and Insurance, 75(3), 567-591.

Elshafie, M. (2013). Research Paradigms: The Novice Researcher's Nightmare. Arab World English Journal, 4(2).

Fazlzadeh, A., Hendi, A. T., \& Mahboubi, K. (2011). The examination of the effect of ownership structure on firm performance in listed firms of Tehran stock exchange based on the type of the industry. International Journal of Business and Management, 6(3), 249.

Foong, S.-Y., \& Idris, R. (2012). Leverage, product diversity and performance of general insurers in Malaysia. The Journal of Risk Finance, 13(4), 347-361.

Gharbi, M., \& Jarboui, A. (2017). Institutional investors' role in diversifying orientation decision across Tunisian companies. Cogent Economics \& Finance, 5(1), 1244873.

Ghaleb, B. A. A., Kamardin, H., \& Tabash, M. I. (2020). Family ownership concentration and real earnings management: Empirical evidence from an emerging market. Cogent Economics \& Finance, 8(1), 1751488.

Greenaway, D., Guariglia, A., \& Yu, Z. (2014). The more the better? Foreign ownership and corporate performance in China. The European Journal of Finance, 20(7-9), 681-702.

Harris, R. D., \& Tzavalis, E. (1999). Inference for unit roots in dynamic panels where the time dimension is fixed. Journal of econometrics, 91(2), 201-226.

Hawawini, G., Subramanian, V., \& Verdin, P. (2003). Is performance driven by industry-or firm-specific factors? A new look at the evidence. Strategic Management Journal, 24(1), $1-16$.

Hermalin, B. E., \& Katz, M. L. (2000). Corporate diversification and agency. Incentives, Organization, and Public Economics: Papers in Honour of Sir James Mirrlees, 17-39.

Copyright (C) 2021, Journal of Advanced Research in Economics and Administrative Sciences (JAREAS), Under a Creative Commons Attribution 4.0 International License 
Hewa Wellalage, N., \& Locke, S. (2015). Impact of ownership structure on capital structure of New Zealand unlisted firms. Journal of Small Business and Enterprise Development, 22(1), 127-142.

Hintošová, A. B., \& Kubíková, Z. (2016). The effect of the degree of foreign ownership on firms' performance. Review of Economic Perspectives, 16(1), 29-44.

Hitt, M. A., Hoskisson, R. E., \& Kim, H. (1997). International diversification: Effects on innovation and firm performance in product-diversified firms. Academy of Management Journal, 40(4), 767-798.

Hossain, M., Prevost, A. K., \& Rao, R. P. (2001). Corporate governance in New Zealand: The effect of the 1993 Companies Act on the relation between board composition and firm performance. Pacific-Basin Finance Journal, 9(2), 119-145.

Huang, R. D., \& Shiu, C. Y. (2009). Local effects of foreign ownership in an emerging financial market: Evidence from qualified foreign institutional investors in Taiwan. Financial management, 38(3), 567-602.

Hussain Tahir, S. (2015). Institutional ownership and corporate value: evidence from Karachi stock exchange (KSE) 30-index Pakistan. Praktični menadžment: stručni časopis za teoriju i praksu menadžmenta, 6(1), 41-49.

Im, K. S., Pesaran, M. H., \& Shin, Y. (2003). Testing for unit roots in heterogeneous panels. Journal of econometrics, 115(1), 53-74.

Iqbal, A., Hameed, I., \& Qadeer, M. (2012). Impact of diversification on firms' performance. American Journal of Scientific Research, 80, 42-53.

Jensen, M. C. (1986). Agency costs of free cash flow, corporate finance, and takeovers. The American economic review, 76(2), 323-329.

Jensen, M. C., \& Meckling, W. H. (1976). Theory of the firm: Managerial behavior, agency costs and ownership structure. Journal of Financial Economics, 3(4), 305-360.

Jensen, M. C., \& Murphy, K. J. (1990). Performance pay and top-management incentives. Journal of political economy, 98(2), 225-264.

Jouida, S., \& Hellara, S. (2018). Diversification, capital structure, and performance: A simultaneous equation approach. Managerial and Decision Economics, 39(2), 117-130.

Kimura, F., \& Kiyota, K. (2007). Foreign-owned versus Domestically-owned Firms: Economic Performance in Japan. Review of Development Economics, 11(1), 31-48.

Klapper, L., \& Love, I. (2011). The impact of the financial crisis on new firm registration. Economics Letters, 113(1), 1-4.

Krivokapic, R., Njegomir, V., \& Stojic, D. (2017). Effects of corporate diversification on firm performance: evidence from the Serbian insurance industry. Economic researchEkonomska istraživanja, 30(1), 1224-1236.

Leech, D., \& Leahy, J. (1991). Ownership structure, control type classifications and the performance of large British companies. The Economic Journal, 101(409), 1418-1437.

Levin, A., Lin, C.-F., \& Chu, C.-S. J. (2002). Unit root tests in panel data: asymptotic and finitesample properties. Journal of econometrics, 108(1), 1-24.

Li, K., Yue, H., \& Zhao, L. (2009). Ownership, institutions, and capital structure: Evidence from China. Journal of comparative economics, 37(3), 471-490.

Copyright (C) 2021, Journal of Advanced Research in Economics and Administrative Sciences (JAREAS), Under a Creative Commons Attribution 4.0 International License 
Lin, Y. R., \& Fu, X. M. (2017). Does institutional ownership influence firm performance? Evidence from China. International Review of Economics \& Finance, 49, 17-57.

Manyuru, A., Wachira, M., \& Amata, E. (2017). The impact of corporate diversification on firm value in Kenya. African Journal of Business Management, 11(11), 241-249.

Markowitz, H. (1952). Portfolio selection. The Journal of finance, 7(1), 77-91.

Masry, M. (2016). The Impact of Institutional Ownership on the Performance of Companies Listed In the Egyptian Stock Market. IOSR Journal of Economics and Finance (IOSR$J E F), 7,5-15$.

McCann, B. T., \& Vroom, G. (2009). Ownership Structure, Profit Maximization, and Competitive Behavior. Paper presented at the Academy of Management Proceedings.

Mi Choi, H., Sul, W., \& Kee Min, S. (2012). Foreign board membership and firm value in Korea. Management Decision, 50(2), 207-233.

Mihai, I. O. (2012). Foreign Owned Companies and Financial Performance. A Case Study on Companies Listed on Bucharest Stock Exchange. Annals of the University Dunarea de Jos of Galati: Fascicle: I, Economics \& Applied Informatics, 18(1).

Monteforte, D., \& Staglianò, R. (2015). Firm complexity and capital structure: Evidence from Italian diversified firms. Managerial and Decision Economics, 36(4), 205-220.

Montgomery, C. (1994). Corporate Diversification: The Journal of Economic Perspectives: California: Oxford University Press.

Moore, T., \& Mirzaei, A. (2016). The impact of the global financial crisis on industry growth. The Manchester School, 84(2), 159-180.

Nakano, M., \& Nguyen, P. (2013). Foreign ownership and firm performance: evidence from Japan's electronics industry. Applied Financial Economics, 23(1), 41-50.

Nzioka, S. (2017). The Relationship between Diversification Strategies and Capital Structure of Non-Financial Firms Listed At the NSE. KCA University.

Ongore, V. O. (2011). The relationship between ownership structure and firm performance: An empirical analysis of listed companies in Kenya. African Journal of Business Management, 5(6), 2120-2128.

Opler, T. C., \& Titman, S. (1994). Financial distress and corporate performance. The Journal of finance, 49(3), 1015-1040.

Oxelheim, L., \& Randøy, T. (2003). The impact of foreign board membership on firm value. Journal of Banking \& Finance, 27(12), 2369-2392.

Oyekunle Oyewobi, L., Olukemi Windapo, A., \& Cattell, K. S. (2013). Impact of business diversification on South African construction companies' corporate performance. Journal of Financial Management of Property and Construction, 18(2), 110-127.

Palich, L. E., Cardinal, L. B., \& Miller, C. C. (2000). Curvilinearity in the diversificationperformance linkage: an examination of over three decades of research. Strategic Management Journal, 21(2), 155-174.

Pavić, I., \& Pervan, M. (2010). Effects of corporate diversification on its performance: The case of Croatian non-life insurance industry. Ekonomska misao i praksa(1), 49-66.

Pawaskar, V. (1999). Effect of product market diversification on firm performance: a study of the Indian corporate sector. Unpublished PhD. dissertation. Indira Gandhi Institute of Development Research, Mumbai.

Copyright (C 2021, Journal of Advanced Research in Economics and Administrative Sciences (JAREAS), Under a Creative Commons Attribution 4.0 International License 
Pervan, M., Pervan, I., \& Todoric, M. (2012). Firm ownership and performance: Evidence for Croatian listed firms. World Academy of Science, Engineering and Technology, 61(2012), 964-970.

Phillips, D. C., \& Burbules, N. C. (2000). Postpositivism and educational research: Rowman \& Littlefield.

Phung, D. N. (2015). Ownership structure, corporate diversification, and firm performance: a study of listed firms in Vietnam.

Phung, D. N., \& Mishra, A. V. (2016). Ownership structure and firm performance: Evidence from Vietnamese listed firms. Australian Economic Papers, 55(1), 63-98.

Phung, D. N., Phan, T. B. N., Nguyen, T. L. H., \& Le, T. P. V. (2016). Ownership structure and corporate diversification decision: a study of Vietnamese listed firms. Corporate Ownership \& Control, 227.

Saleh, M., Zahirdin, G., \& Octaviani, E. (2017). Ownership structure and corporate performance: evidence from property and real estate public companies in Indonesia. Investment Management \& Financial Innovations, 14(2), 252.

Salma, U., \& Hussain, A. (2018). A Comparative Study on Corporate Diversification and Firm Performance across South Asian Countries. Journal of Accounting \& Marketing, 7, 1-7.

Shleifer, A., \& Vishny, R. W. (1997). A survey of corporate governance. The Journal of finance, 52(2), 737-783.

Thai, A. (2019). The Effect of Foreign Ownership on Capital Structure in Vietnam. Review of Integrative Business and Economics Research, 8(1), 20-32.

Thomsen, S., \& Pedersen, T. (2000). Ownership structure and economic performance in the largest European companies. Strategic Management Journal, 21(6), 689-705.

van Oijen, A. A., \& Hendrikse, G. W. (2002). Governance structure, product diversification, and performance.

Xu, G., Ou, X., \& Chen, X. (2016). Research on the relationship between debt financing and operating performance based on mediation of diversification. Technology and Investment, 7(03), 66.

Zhang, H., \& Kyaw, K. (2016). Ownership structure and firm performance: An empirical analysis of Chinese companies. Applied Economics and Finance, 4(2), 57-64.

Zhao, X., Lynch Jr, J. G., \& Chen, Q. (2010). Reconsidering Baron and Kenny: Myths and truths about mediation analysis. Journal of consumer research, 37(2), 197-206.

Zraiq, M. A. A., \& Fadzil, F. H. B. (2018). The impact of ownership structure on firm performance: Evidence from Jordan. International Journal of Accounting, Finance and Risk Management, 3(1), 1-4.

Copyright (C 2021, Journal of Advanced Research in Economics and Administrative Sciences (JAREAS), Under a Creative Commons Attribution 4.0 International License 